\title{
Beyond Deforestation: Carbon Emissions From Land Grabbing and Forest Degradation in the Brazilian Amazon
}

\author{
Sanne Kruid ${ }^{1 *}$, Marcia N. Macedo ${ }^{1,2 *}$, Seth R. Gorelik ${ }^{1}$, Wayne Walker', \\ Paulo Moutinho',2, Paulo M. Brando 1,2,3, Andrea Castanho', Ane Alencar', \\ Alessandro Baccini ${ }^{1,4}$ and Michael T. Coe ${ }^{1,2}$ \\ ${ }^{1}$ Woodwell Climate Research Center (Woodwell), Falmouth, MA, United States, ${ }^{2}$ Instituto de Pesquisa Ambiental da \\ Amazônia (IPAM), Brasilia, Brazil, ${ }^{3}$ Department of Earth System Science, University of California, Irvine, Irvine, CA, \\ United States, ${ }^{4}$ Department of Earth and Environment, Boston University, Boston, MA, United States
}

Carbon losses from forest degradation and disturbances are significant and growing sources of emissions in the Brazilian Amazon. Between 2003 and 2019, degradation and disturbance accounted for $44 \%$ of forest carbon losses in the region, compared with

OPEN ACCESS

Edited by:

Metodi Sotirov

University of Freiburg, Germany

Reviewed by:

Francis Edward Putz,

University of Florida, United States

Selene Báez,

Escuela Politécnica Nacional, Ecuador

${ }^{*}$ Correspondence:

Sanne Kruid

sannekruid@hotmail.com

Marcia N. Macedo

mmacedo@woodwellclimate.org

Specialty section: This article was submitted to

Tropical Forests,

a section of the journal

Frontiers in Forests and Global

Change

Received: 22 December 2020 Accepted: 01 July 2021

Published: 27 July 2021

Citation:

Kruid S, Macedo MN, Gorelik SR Walker W, Moutinho P, Brando PM, Castanho A, Alencar A, Baccini A and Coe MT (2021) Beyond Deforestation:

Carbon Emissions From Land Grabbing and Forest Degradation in the Brazilian Amazon.

Front. For. Glob. Change 4:645282. doi: 10.3389/ffgc.2021.645282
$56 \%$ from deforestation (forest clearing). We found that land tenure played a decisive role in explaining these carbon losses, with Undesignated Public Forests and Other Lands (e.g., private properties) accounting for the majority (82\%) of losses during the study period. Illegal deforestation and land grabbing in Undesignated Public Forests widespread and increasingly are important drivers of forest carbon emissions from the region. In contrast, indigenous Territories and Protected Natural Areas had the lowest emissions, demonstrating their effectiveness in preventing deforestation and maintaining carbon stocks. These trends underscore the urgent need to develop reliable systems for monitoring and reporting on carbon losses from forest degradation and disturbance. Together with improved governance, such actions will be crucial for Brazil to reduce pressure on standing forests; strengthen Indigenous land rights; and design effective climate mitigation strategies needed to achieve its national and international climate commitments.

Keywords: forest degradation, emissions, land tenure, undesignated public forests, land grabbing, Amazon

\section{INTRODUCTION}

Stopping emissions from deforestation and forest degradation is essential for tropical nations to achieve their climate mitigation targets, and for the world to avoid the worst impacts of climate change. Nevertheless, forest carbon losses remain a major source of greenhouse gas (GHG) emissions in countries like Brazil (Figure 1A), which holds the largest remaining tract of tropical forest in the world (Moutinho et al., 2016). In the Brazilian Amazon, emissions from deforestation-defined as clear-cutting of forests for conversion to land uses such as agriculture or ranching-have risen substantially since 2017 (de Azevedo et al., 2018; SEEG, 2021). In terms of area, deforestation reached $10,900 \mathrm{~km}^{2}$ in 2019 and topped $11,088 \mathrm{~km}^{2}$ in 2020 [Instituto Nacional de Pesquisas Espaciais (INPE), 2020; Figure 1B]. This recent trend signals a dramatic reversal of deforestation control strategies implemented in the early 2000s, putting Brazil 180\% above the 2020 deforestation target established in its National Climate Change Policy (Nepstad et al., 2014). 
Land tenure and governance have exerted a strong influence over land-use trajectories throughout Brazil's history (e.g., West and Fearnside, 2021). In the Amazon forest biome, the Brazilian Forest Code requires that $80 \%$ of the land area on private properties be set aside as permanent forest reserves. Although the law permits some legal forest clearing $(20 \%)$, the recent spike in deforestation has been attributed to illegal activities such as unpermitted clearing of forests on private properties; illegal mining and logging; land grabbing in Undesignated Public Forests (UPFs); and invasions of Protected Natural Areas (PNAs) and Indigenous Territories (ITs) (Alencar et al., 2019). UPFs, which span $15 \%$ (between 0.5 and 0.62 million $\mathrm{km}^{2}$ ) of the Brazilian Amazon Forest biome, have also become hotspots of illegal deforestation in recent years. These state and federal lands lack clear zoning or land-use designations, making them highly vulnerable to land grabbing and associated carbon losses (Azevedo-Ramos et al., 2020, Azevedo-Ramos and Moutinho, 2018). In contrast, legal recognition of ITs and clear demarcation of PNAs have proven extremely effective in improving governance and slowing deforestation over 2.1 million $\mathrm{km}^{2}(50 \%)$ of forests in the region (Walker et al., 2020).

As illegal deforestation increased, so did the fires typically associated with forest clearing (i.e., burning of residual biomass after trees are felled), which fueled record fire seasons in 2019 and 2020 (Alencar et al., 2019). High deforestation rates, combined with a regional climate that is becoming warmer and drier, have increased the number of intentional fires and ignited (unintentional) understory wildfires that tend to burn hotter and longer than they used to (Barlow et al., 2020; Brando et al., 2020). From January 1 to August 29, 2019, the Brazilian Institute of Space Research (INPE) identified over 45,000 active fires in the Amazon biome, a marked increase in fire activity compared with the previous 8 years (Alencar et al., 2019). Observations indicate that 2020 was even worse-from January to December 2020 the Amazon saw a 16\% increase in fire counts $(103,161)$ compared to the previous year $(89,178)$ (INPE, 2021). These fires shrouded the region in a blanket of smoke that reduced air quality for millions of people, increasing hospitalizations due to respiratory illnesses and exacerbating the on-going public health emergency associated with Covid-19 [HRW et al., 2020; Fiocruz and ICICT, 2021].

As deforestation has intensified in the region, so have other drivers of forest degradation. These processes may cause measurable forest biomass losses even where standing forests remain (i.e., the forest remains forest, but with reduced aboveground carbon density; Baccini et al., 2017; Walker et al., 2020). Degradation from anthropogenic activities such as selective logging, fire, mining, and oil extraction-much of it occurring illegally in protected forests (ITs and PNAs) and UPFs-is an increasingly important driver of carbon emissions from tropical forests (Figure 3). Such human-induced degradation may be compounded by natural disturbances and indirect impacts of deforestation, including edge effects that expose forests to wind, higher temperatures, understory drying, grass invasion, and fire (Laurance, 2000; Brinck et al., 2017; Silvério et al., 2019). These stressors increase tree mortality, causing dead biomass to accumulate and increase fuel loads, which further increase the risk of forest fires that kill trees (Cochrane et al., 1999; Silvério et al., 2019), thereby setting up a vicious cycle of positive feedbacks (Nepstad et al., 2001).

While Amazon forests evolved with natural disturbances (e.g., large blowdowns, seasonal flooding, tree fall gaps), in the past their carbon losses were balanced by post-disturbance recovery and regrowth (Houghton et al., 2000; Nobre et al., 1991). Today, there is growing evidence that novel disturbance regimes are promoting unusual biomass losses (Nobre et al., 2016). Likewise, fire has long been used in Brazilian land management, but regional warming and drying have created novel conditions that allow fire to spread more rapidly and burn more intensely, resulting in increased tree mortality (Barlow et al., 2003; Lewis et al., 2011; Silva et al., 2018). Together, these shifts in disturbance and degradation processes may decrease the overall ecological integrity and resilience of Amazon forests, and thus alter their carbon balance.

Over the last decade, the combined effects of degradation, disturbance, and deforestation have hindered the capacity of tropical forests to absorb carbon (net) over the short term (Brienen et al., 2015; Baccini et al., 2017; Hubau et al., 2020). Some estimates suggest that the area affected by these more cryptic carbon losses was almost as high as the area deforested from 1995-2017 (Bullock et al., 2020). Although tropical forests remain a globally important reservoir of forest carbon, recent evidence suggests that the carbon sink in standing forests may be slowing due to the combined effects of deforestation and degradation from extreme droughts (Phillips et al., 2009; Pan et al., 2011; Brienen et al., 2015), fire activity, edge effects (Junior et al., 2020), mining, and selective logging (Maxwell et al., 2019). When taken together, these factors have shifted the Brazilian Amazon toward being either net neutral or a net source of carbon to the atmosphere (Figures 1-3), thus offsetting the strong carbon sink associated with healthy tropical forests (Baccini et al., 2017; Walker et al., 2020; Harris et al., 2021).

While emissions from deforestation have been monitored consistently in the Brazilian Amazon, estimates of emissions from degradation and disturbance in the region still vary widely-largely because of inconsistencies in the operational definition of disturbance (Asner et al., 2005; Hansen et al., 2013; Souza et al., 2013; Tyukavina et al., 2017; Aragão et al., 2018; Bullock et al., 2020). Moreover, we know relatively little about how different land tenure strategies (protected vs. unprotected) determine forest trajectories and carbon emissions over the long term (Walker et al., 2020). Several studies have demonstrated that unclear land tenure (e.g., in UPFs) encourages illegal deforestation (Azevedo-Ramos et al., 2020, AzevedoRamos and Moutinho, 2018), but few have quantified the forest losses and associated biomass changes occurring under different land tenure regimes.

To address this gap, we combine previously published spatial data on forest losses (Hansen et al., 2013) and aboveground biomass change (Walker et al., 2020) with recent information on land tenure (Azevedo-Ramos et al., 2020; RAISG, 2020) to assess the relative contribution of deforestation and forest degradation/disturbance to carbon losses in the Brazilian Amazon. Our time series data on aboveground carbon density 

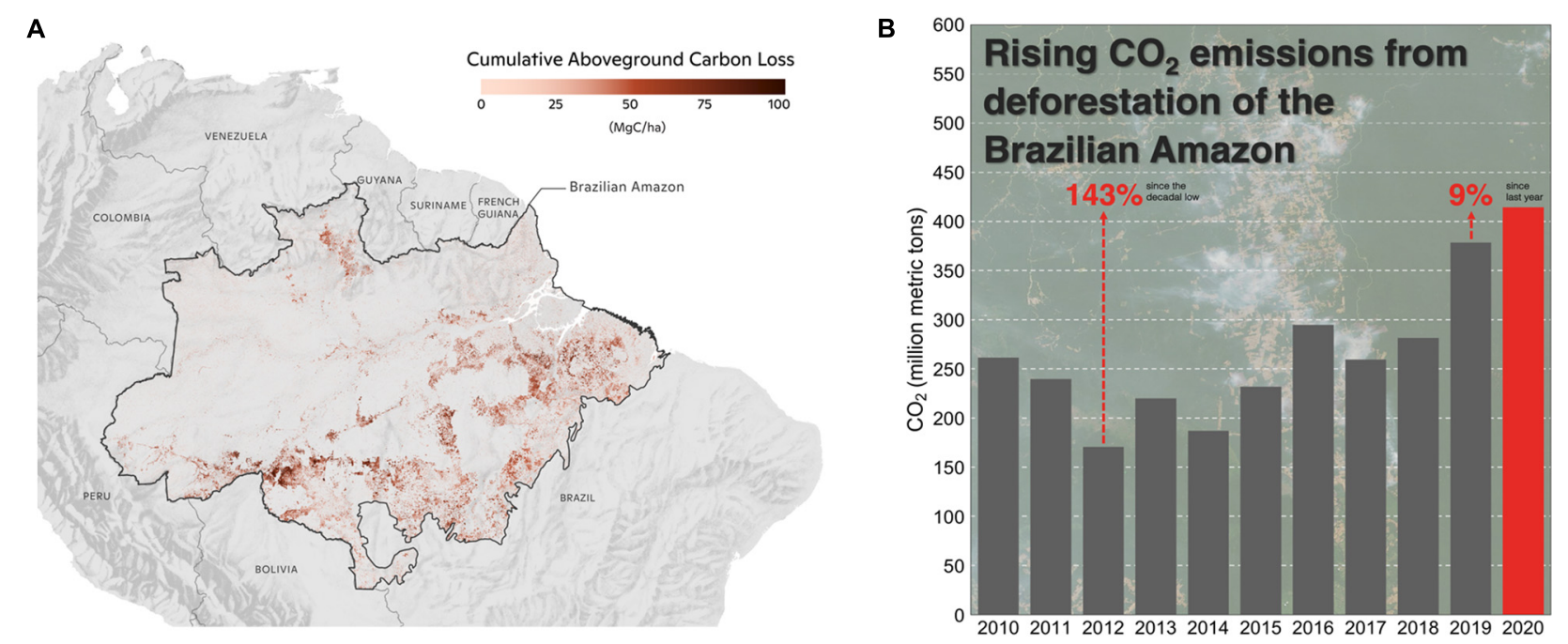

FIGURE 1 | Carbon dynamics in the Brazilian Amazon forest biome. (A) Cumulative aboveground carbon losses (MgC/ha) from 2003 to 2019. (B) Annual carbon dioxide emissions (million metric tons of $\mathrm{CO}_{2}$ ) from deforestation over the last decade. Deforestation data is from the Brazilian National Space Agency [INPE, 2021] and biomass change data is from Walker et al. (2020). Background image depicts smoke from fires following deforestation near Novo Progress, PA, Brazil (MODIS/Terra images from August 19, 2019; NASA Earth Observatory).

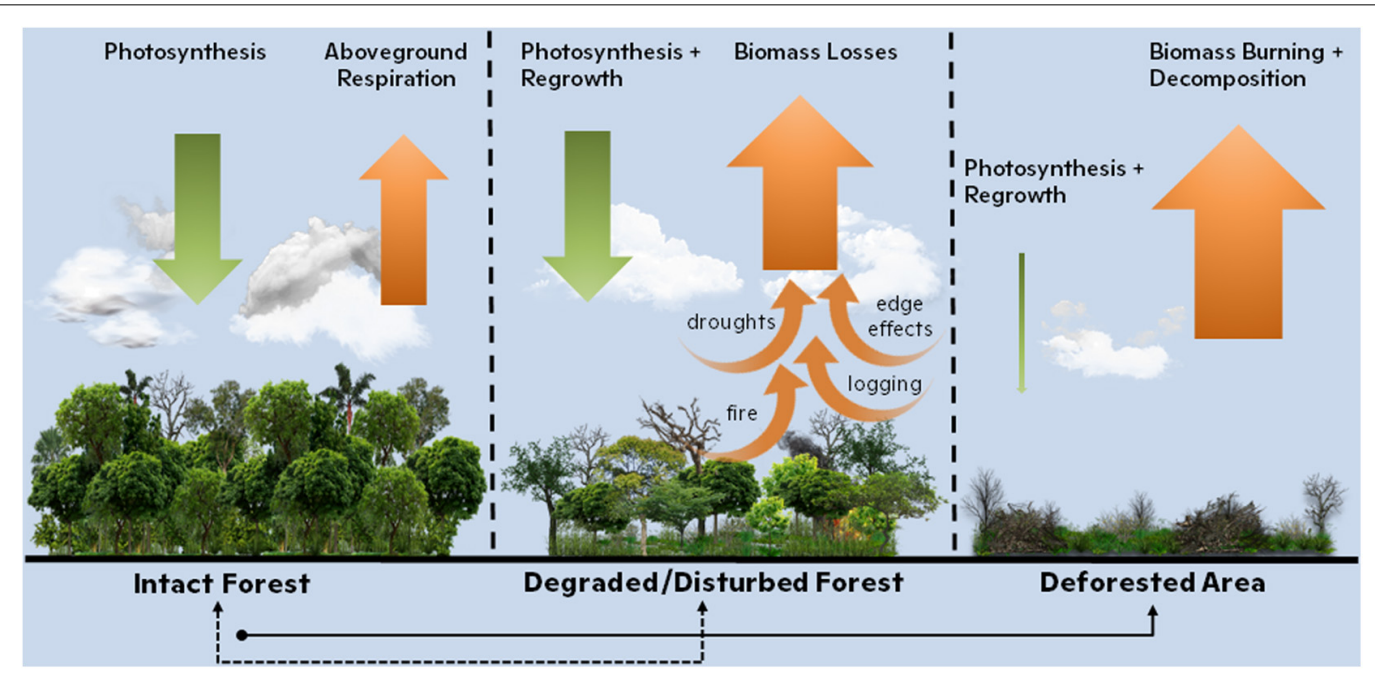

FIGURE 2 | Conceptual diagram showing above-ground carbon fluxes typical of healthy forests (left), degraded/disturbed forests (middle), and newly deforested areas (right) in the Amazon. In each panel, carbon stocks are represented by the standing vegetation, losses by the orange upward arrows, and gains by the green downward arrows. Sources contributing to degradation and disturbance include direct (logging, fire) and indirect (droughts, edge effects) anthropogenic drivers. The one-way, solid black arrow represents forest clearing (deforestation) and conversion to another land use/cover- once deforested, these areas are unlikely to regenerate to an intact forest. The two-way, dashed line reflects degradation/disturbance of intact forests. Depending on the intensity and frequency of disturbances, degraded/disturbed forests may regenerate into intact forests.

(Baccini et al., 2017; Walker et al., 2020) allows reliable tracking of annual carbon losses and gains from 2003-2019 at a spatial resolution of $463 \mathrm{~m} \times 463 \mathrm{~m}$ (21.4 ha). The algorithm is sensitive to changes (gains or losses) in carbon on the order of several tons of $\mathrm{C} \mathrm{ha}{ }^{-1}$ year $^{-1}$ and tracks uncertainty over time. At the pixel scale, carbon losses that persist over time represent real net changes in forest carbon, considering all types of disturbance and degradation together.

Using high-resolution (30-m), annual deforestation data (from Hansen et al., 2013), we can isolate biomass losses from forest clearing from all other biomass changes each year (i.e., degradation/disturbance). We cannot yet attribute forest degradation to specific anthropogenic or natural drivers, but we can examine the overall trajectory of a pixel in terms of biomass losses and gains over years or decades. Here, we analyze the patterns of deforestation and forest degradation from 2003-2019; estimate the magnitude of forest carbon losses attributable to degradation/disturbance; and explore how land management and governance may have influenced the observed patterns. Finally, we make several policy recommendations considering these 


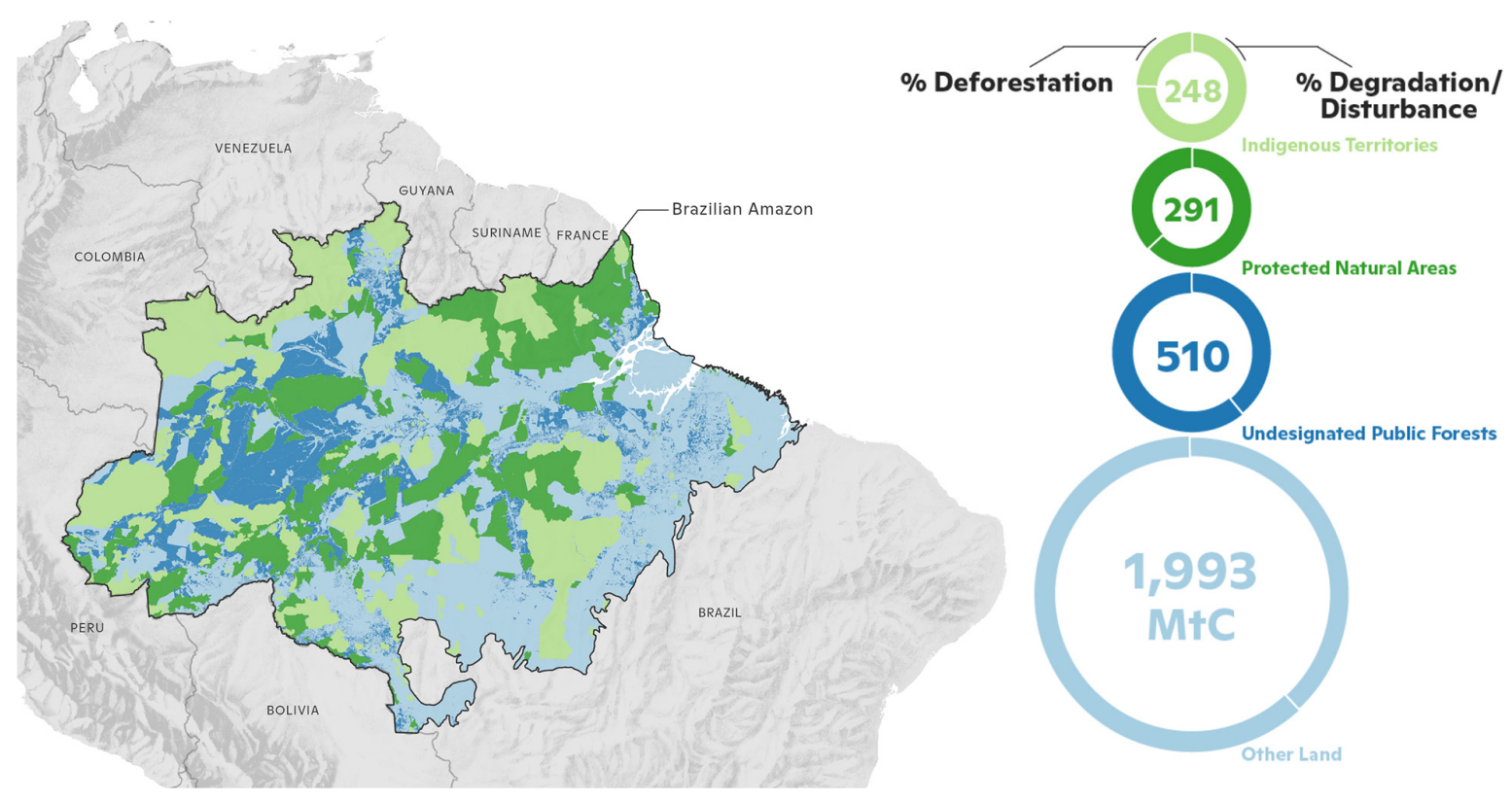

FIGURE 3 | Distribution of land tenure categories in the Brazilian Amazon (left, map), their respective emissions (right, circles), and the relative contribution of deforestation (forest conversion) vs. degradation/disturbance to those emissions (circle slices). The size of the circles represents the relative scale of emissions from each land tenure category. Land tenure data is from Azevedo-Ramos et al. (2020) and RAISG (2020). Emissions attribution data is from Hansen et al. (2013) and Walker et al. (2020).

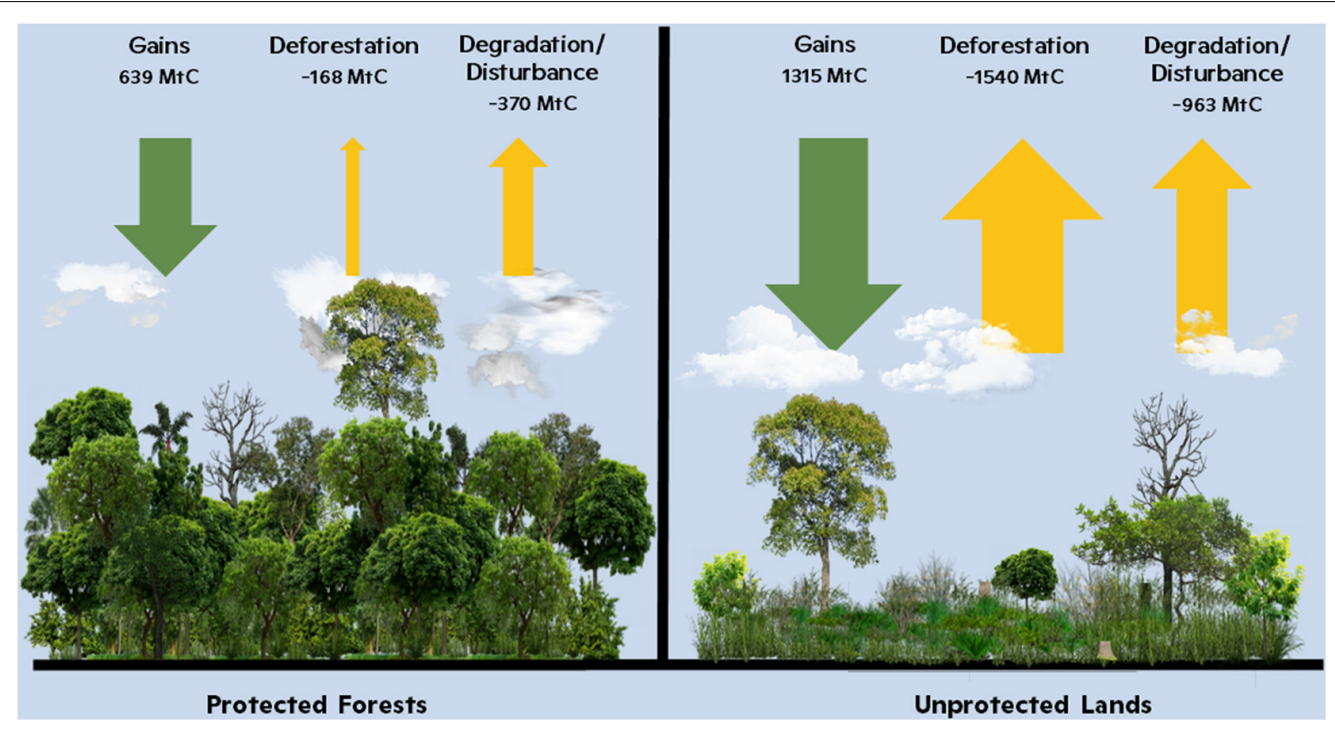

FIGURE 4 | Cumulative (gross) above-ground carbon fluxes from protected forests (left) and unprotected forests (right) between 2003 and 2019 . Protected forests (i.e., Indigenous Territories and Protected Natural Areas) have higher standing carbon stocks, lower rates of deforestation (forest conversion), and less degradation/disturbance than unprotected forests (i.e., Undesignated Public Forests and Other Land). Unprotected forests had higher total carbon gains, presumably due to vegetation regrowth after disturbance, but these gains were more than offset by deforestation and degradation/disturbance.

trends. Because our approach to map forest degradation does not differentiate between natural and anthropogenic disturbances, we present them combined. Although this approach may overestimate anthropogenic disturbances in some years, our relatively long time series should reduce their influence and allow the identification of important spatial and temporal trends.

\section{RESULTS}

From 2003-2019, gross carbon loss from the Brazilian Amazon totaled 3,042 MtC. Most carbon loss (56\%) was attributed to deforestation, with the remainder (44\%) due to forest degradation/disturbance. While the data presented here does not 


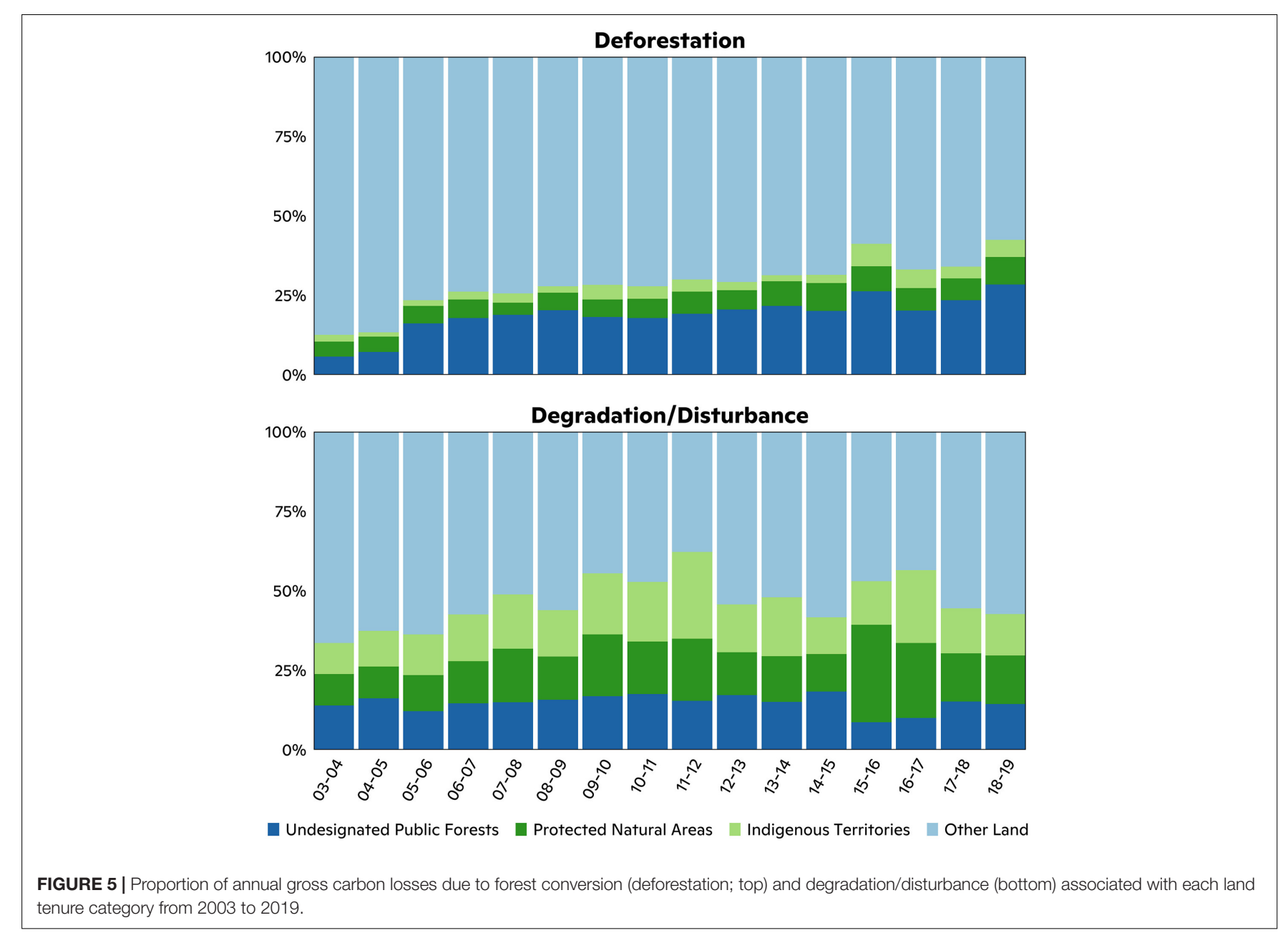

attribute degradation/disturbance to specific causes, it captures the cumulative effect of biomass losses due to fire, natural disturbances, drought-induced tree mortality, edge effects, selective logging, and other extractive activities. Carbon losses from deforestation and forest degradation/disturbance varied substantially among different land tenure categories, as described below (Figure 3; Supplementary Table 1).

\section{Land Tenure and Forest Carbon Losses}

Private properties and mixed urban/suburban landscapes (i.e., Other Land, OL) accounted for the bulk of gross aboveground biomass (forest carbon) losses (66\%, or 1,993 MtC) over the study period (Figure 5), followed by UPFs (17\% or $510 \mathrm{MtC}$ ) (Supplementary Table 1). Carbon losses per unit land area from UPFs totaled $817 \mathrm{tC} / \mathrm{km}^{2}$, nearly three times the combined carbon losses from ITs and PNAs $\left(277 \mathrm{tC} / \mathrm{km}^{2}\right)$. ITs and PNAs comprised $46 \%$ of the study area but were responsible for just $18 \%$ (539 MtC) of total forest carbon losses over the study period. Nearly $70 \%$ of those losses were attributed to degradation/disturbance rather than deforestation. In contrast, UPFs comprised only $15 \%$ of the study area but contributed nearly the same (510 MtC; 17\%) cumulative biomass losses over the study period (Supplementary Table 1).
The relative contributions of deforestation and degradation/disturbance to carbon losses varied across land tenure categories, especially between unprotected forests (i.e., UPFs and a large proportion of OL) and protected forests (PNAs and ITs; Figures 4, 5). Deforestation accounted for $61 \%$ and $62 \%$ of carbon losses from UPFs and OL, respectively, whereas degradation/disturbance dominated gross carbon losses from ITs (75\%) and PNAs (63\%). Overall, carbon losses from deforestation in protected forests (ITs and PNAs combined; $168 \mathrm{MtC}$ ) were over 9 times lower than in unprotected forests (UPFs and OL combined; 1,540 MtC). ITs had the lowest gross carbon losses (248 MtC) of the four land tenure categories, followed by PNAs (291 MtC; Supplementary Table 1).

\section{Illegal Deforestation and Land Grabbing}

Most cumulative carbon losses (i.e., since deforestation monitoring began) have occurred in areas defined here as "Other Land," some of which may be attributable to legal deforestation on private properties. However, we found a clear shift in the pattern of deforestation in UPFs in the Brazilian Amazon. Over the course of the study period, deforestation in UPFs increased steadily from $\sim 6 \%$ of gross carbon losses in 2003-2004 to over 28\% in 2018-2019 (Figure 5 and Supplementary Figure 1). 
Since all clearing in UPFs is prohibited by law, virtually all cumulative carbon losses from UPFs were attributable to illegal deforestation (61\%) or degradation/disturbance (39\%). Illegal deforestation in ITs and PNAs also increased (by 84 and 42\%, respectively) from early (2003-2011) to late (2011-2019) in the study period (S1). Despite this increase, carbon losses in ITs and PNAs remained low, both in absolute terms and relative to carbon losses in other land tenure categories.

\section{IMPLICATIONS}

If deforestation and degradation/disturbance are not curtailed rapidly, Brazil will fail to meet its 2025 climate target-to reduce GHG emissions by $37 \%$ relative to 2005 (Climate Action Tracker, 2020; UNFCCC, 2020). Our findings suggest that many regions in the Brazilian Amazon are moving in the opposite direction, with substantial increases in illegal deforestation and growing emissions from degradation/disturbance. These results agree with previous studies indicating that degradation and disturbance of intact forests are eroding carbon stocks and reducing the capacity of forests to absorb carbon from the atmosphere (Maxwell et al., 2019; Junior et al., 2020; Matricardi et al., 2020). They also underscore the importance of governance and clear land tenure in determining - and ultimately reversingthese trends (Figure 5).

Our findings confirm previous work showing that protected forests of all types are effective at preventing deforestation and protecting carbon stocks (Soares-Filho et al., 2010; PorterBolland et al., 2012; Barber et al., 2014; Walker et al., 2014; Spracklen et al., 2015; Azevedo-Ramos and Moutinho, 2018). ITs and PNAs contributed fewer carbon losses than any other land category. ITs had the lowest losses of all, protecting nearly onethird of forest carbon in the Brazilian Amazon and demonstrating that Indigenous people have been effective land stewards helping to maintain the integrity of forest carbon stocks.

At the same time, land speculation and land grabbing have increased throughout the region (Escobar, 2019a). Our analysis confirms that UPFs are especially susceptible to carbon losses and would greatly benefit from formal protection. Forest losses in UPFs have recently increased, marking a longterm shift from private properties as the primary source of deforestation to public lands becoming a dominant source. By 2019, a third of all observed deforestation occurred in UPFs (Alencar et al., 2019). All deforestation in these public forests is illegal by definition-likely linked to a regulatory environment that has encouraged land speculation in areas where there is no clear land tenure. This pattern suggests that the lack of governance in UPFs has become an increasingly important factor driving deforestation, a symptom of land grabbing and other illegal activities (Azevedo-Ramos and Moutinho, 2018) such as mining and drug trafficking (Fearnside, 2008).

No public agency has clear jurisdiction over the management of the large area of UPFs (Azevedo-Ramos and Moutinho, 2018). Moreover, there is considerable uncertainty about the exact area and location of these lands. The results presented here consider the area of state and federal UPFs reported by the Brazilian Forest Service ( $\sim 62$ Mha; SFB, 2017), but recent studies have identified conflicting land claims that could reduce the area in question substantially ( 50 Mha; Azevedo-Ramos et al., 2020). Addressing these inconsistencies would require state or federal governments to review conflicting claims and legally designate these areas (e.g., to a protected area, sustainable use area, or rural settlement) in line with the Public Forests Management Act (Alencar et al., 2019). Absent such legal action, UPFs will remain highly susceptible to illegal land grabbingas evidenced by the $\sim 2.6$ Mha deforested illegally by 2018 and by the 11.6 Mha of fraudulent land claims registered as private properties in Brazil's national land registry (CAR; Azevedo-Ramos et al., 2020).

Several factors have contributed to the recent spike in deforestation and degradation/disturbance reported here. Regional and global climate change, for example, have decreased the resilience of forests, making them more vulnerable to disturbances such as fires and edge effects (Matricardi et al., 2020). In addition, the administration of President Jair Bolsonaro has presided over rollbacks of protective policies and budget cuts for government agencies in charge of environmental enforcement (IBAMA) and indigenous affairs (FUNAI) (Raftopoulos and Morley, 2020). With weaker monitoring and management of ITs and PNAs (Artaxo, 2019; Escobar, 2019b), an increase in illegal invasions and escaped fires contributed to growing carbon losses from protected forests after 2018. Moreover, the land rights of Indigenous people and local communities have been undermined through negligence (e.g., allowing illegal invasions and fires to proceed unchecked); failure to implement the law (e.g., halting the demarcation of new ITs); and attempts to roll back existing land rights or promote land uses incompatible with forest conservation in ITs (Raftopoulos and Morley, 2020).

\section{RECOMMENDATIONS}

Designing effective climate mitigation strategies requires the complete and accurate accounting of forest carbon losses, their associated emissions, and their underlying drivers. All are key for Brazil and other tropical countries to achieve their commitments under the Paris Climate Agreement. Recent work suggests that the scale of carbon losses from forest degradation and disturbance is approaching that of carbon losses from deforestation. Despite this observation, most tropical nations only account for deforestation in their annual emissions estimates. By overlooking potentially large and growing sources of GHG emissions from Amazon forests, the signatories of the Paris Agreement could greatly underestimate carbon emissions and miss opportunities to slow or reverse degradation/disturbance over the long run. Moreover, our analyses for Brazil suggest that land tenure plays a decisive role in the vulnerability of forests to deforestation, degradation, and disturbance. Again, few nations have implemented comprehensive accounting. Following are recommendations for addressing this predicament in the Brazilian Amazon, based on the data presented here. 


\section{Combat Illegal Land Grabbing in Undesignated Public Forests}

Formally protecting or clarifying land tenure in UPFs is critical to combat illegal land grabbing, deforestation, and degradation/disturbance in the Brazilian Amazon (AzevedoRamos et al., 2020). These actions would not only slow illegal occupation of these lands by closing legislative loopholes, but also prevent fraudulent land claims and associated land clearing (Brown et al., 2016; Sparovek et al., 2019). Slowing illegal deforestation would also reduce ignition sources that promote wildfires in the landscape, which contribute to forest degradation/disturbance (Alencar et al., 2019). If the Brazilian government allocated UPFs to social uses (e.g., community use, forest rural settlements, TIs) or conservation designations (e.g., PNAs), it could reduce the supply of unsupervised land; increase de facto forest protection; and slow deforestation, degradation/disturbance, and their associated carbon losses (Azevedo-Ramos and Moutinho, 2018).

The Consortium of Amazon Governors, representing all states in the Brazilian Amazon, could play a leading role in demanding designation of UPFs in their states. Ambitious state and municipal plans have the potential to reduce deforestation and promote low-emissions development at the state level, even in the absence of political will at the federal level. By facilitating political engagement, decentralized initiatives could enhance the capacity of state and local governments to fight deforestation, address the drivers of degradation/disturbance, and secure funding for complementary strategies and programs. Addressing the drivers of illegal deforestation in UPFs also represents a real opportunity to advance the broader agenda of the Governors' Climate and Forests Task Force (GCFTF, 2017).

\section{Strengthen Indigenous Land Rights}

Formal recognition of Indigenous territories is crucial for reducing deforestation, maintaining a stable regional climate, mitigating global climate change, preserving biodiversity, and sustaining local livelihoods (Soares-Filho et al., 2010; Nolte et al., 2013; Walker et al., 2020). Guaranteeing the rights of Indigenous people to their land and self-determination is also a matter of social and climate justice. The main policy mechanisms for doing this are through enforcement of Article 231 of Brazil's Federal Constitution (Fellows et al., 2020) and the United Nations Declaration on the Rights of Indigenous Peoples (UNDRIP; UNDESA, 2007). Article 231 describes the responsibility of the Brazilian government to demarcate, protect, and respect ITs and their assets. Brazil is also a signatory to the UNDRIP, which specifies that countries "shall give legal recognition and protection to these (Indigenous) lands, territories, and resources" (UNDESA, 2007, Article 26.3).

Despite their outsized role in combatting climate change through forest conservation, Indigenous peoples do not yet have official seats at the table for international climate negotiations. Amazon Indigenous coalitions such as COIAB (the Coordination of Indigenous Organizations of the Brazilian Amazon) have sent delegations to annual climate talks since 2000, yet today all Indigenous peoples remain non-voting "observers" to the negotiations surrounding the United Nations Framework Convention on Climate Change (UNFCCC). The international community could play an important role in guaranteeing land rights and decision-making power for Indigenous people through formal recognition of their contribution to and leadership on climate change mitigation.

\section{Reduce Pressure on Standing Forests}

Despite the dominant narrative claiming that forest protection comes at the cost of development, measures to reduce pressure on forests can also provide economic benefits. For example, creating financial mechanisms to compensate landowners who forego their right to (legally) deforest portions of their land could help incentivize additional forest conservation on private lands (Stabile et al., 2020). These could include existing mechanisms such as REDD + or the environmental reserve quotas established under Brazil's Forest Code, as well as new approaches (SoaresFilho et al., 2016). Such mechanisms have the potential to create a new bioeconomy that values (and in some cases monetizes) intact forests and the globally important services they provide.

Promoting more efficient use of already cleared land could likewise help reduce pressure on forests while increasing agricultural output (Strassburg et al., 2014; Stabile et al., 2020). This could include financial assistance to small-holders to help sustain production, improve livelihoods, and reduce the need to use slash-and-burn practices. Intensifying production on existing large ranches and farms (Strassburg et al., 2017) could also help reduce pressure on forests, provided these measures are combined with effective policies to improve governance and enforce forest protection (Macedo et al., 2012; Ceddia et al., 2014). Finally, an emerging and potentially effective way to reduce pressure on forests is to reduce demand for agricultural land by diversifying diets and reducing meat consumption, particularly beef (Roe et al., 2019). Taken together, these approaches would go a long way toward reducing the incentives for deforestation and helping to mitigate activities that contribute to forest degradation and disturbance (e.g., edge effects, fragmentation, fire ignition sources, and extractive activities).

\section{Monitor and Report on Emissions From Forest Degradation and Disturbance}

Accurately tracking forest carbon emissions will require integrating degradation and disturbance into national forest monitoring systems. The approach presented here could facilitate consistent mapping and monitoring of carbon losses from degradation at national scales, but tracking aggregate losses will not be insufficient to mitigate those losses. Reducing carbon losses from forest degradation would require further research to attribute observed losses to specific anthropogenic drivers that can then be targeted for management. That attribution is beyond the scope of this study but could be accomplished by combining the biomass data presented here with maps of specific land-use changes and disturbance types.

Measuring and monitoring forest degradation/disturbance present some unique challenges: many processes happen below 
the forest canopy (Matricardi et al., 2020) and their emissions can be lagged, occurring years or even decades after the initial disturbance. Recent advances in mapping, monitoring, and attribution of forest fires, the largest source of degradation and disturbance, may help address these challenges (Curtis et al., 2018; de Azevedo et al., 2018; Andela et al., 2019; MapBiomas, 2020; Silva et al., 2020). Using new spatial datasets to track degradation and emissions from forest fires could be a good starting point, complemented by ongoing efforts to map other types of forest degradation (e.g., selective logging, extreme droughts, mining) and land-use changes (e.g., MapBiomas, 2020) over time.

\section{Implement Brazil's Climate Policies and Commitments}

The ultimate drivers of forest degradation and disturbances often originate outside protected lands, but their effects can penetrate deep within protected area borders (Walker et al., 2020). Climate change is a prime example of this, having already contributed to a measurable increase in the frequency and intensity of extreme droughts that kill trees and make wildfires more likely. Addressing climate change is thus of paramount importance to preserving Amazon forests over the long term. At the same time, conserving Amazon forests is a prerequisite for any global solution to the climate crisis. Despite the urgency to act, Brazil again seems to be moving in the opposite direction. Its updated Nationally Determined Contribution (NDC), published in December 2020, reduced the country's climate ambitions by effectively setting a higher baseline as the reference level for 2030 emissions targets and suggesting that its goals to achieve carbon neutrality in 2060 may be contingent on international financing.

Implementing new and existing policies that support a more ambitious NDC will be critical for preserving the Brazilian Amazon and slowing global climate change. At the national scale, the Brazilian Forest Code is among the most important pieces of climate change legislation (Soares-Filho et al., 2014). Combined with implementation of the National Climate Change Policy, enforcement of the Forest Code could play a critical role in putting Brazil back on track to meet the deforestationreduction and economic targets described in their NDC (Angelo and Rittl, 2019). Our analysis could assist in designing specific policies that respond to the challenges of mitigating degradation/disturbance and deforestation under different land tenure types. For example, policy interventions focused on reducing illegal deforestation in UPFs, or degradation in ITs and PNAs, could assist Brazil in meeting its targets under the UN Climate Agreement and the Aichi Biodiversity Convention, while also contributing to the UN Sustainable Development Goals (SDGs) (Supplementary Table 2).

\section{CONCLUSION}

The environmental consequences of deforestation are substantial, but forest degradation and disturbance are also significant and growing sources of GHGs to the atmosphere. Despite this, degradation and disturbance are not reliably accounted for in national emissions estimates. Understanding the drivers and patterns of forest carbon losses is an essential first step for designing effective climate mitigation strategies and will be key for Brazil and other tropical countries to achieve their commitments under the Paris Agreement. Indigenous Territories and Protected Natural Areas are especially important for maintaining aboveground carbon stocks, but they need additional support in the face of growing external pressures. Designating UPFs to curb illegal deforestation and incentivizing private landowners to conserve or restore their forests (i.e., slowing legal deforestation) represent near-term opportunities for Brazil to restore and maintain the Amazon forest as a carbon sink.

\section{DATA AVAILABILITY STATEMENT}

This study presents a synthesis and reanalysis of previously published datasets. Most primary datasets are available via the published studies. The shapefile of undesignated public forests (Azevedo-Ramos et al., 2020) is available at: http://www.florestal. gov.br/cadastro-nacional-de-florestas-publicas. Data on biomass gains and losses (Walker et al., 2020) is available at: https://github. com/whrc/Amazon-Indigenous-Carbon.

\section{AUTHOR CONTRIBUTIONS}

SK: conceptualization, writing-original draft, and review and editing. MM: conceptualization and writing - review and editing. SG and WW: data curation, analysis, and writing-review and editing. PM, AC, PB, MC, AB, and AA: writing-review and editing. All authors contributed to the article and approved the submitted version.

\section{FUNDING}

This research was generously supported by grants from the Norway's International Climate and Forest Initiative (NORAD: BRA 2050 BRA 16/0004, IPAM NICFI 2016/2020 Forest Code Observatory, NICFI: RAM-2019 RAM-16/0003); the Gordon and Betty Moore Foundation (\#5483 and \#9957); the Charles Stewart Mott Foundation (\#2020-06320); NASA’s Carbon Monitoring System project (NNX14AO81G and NNX16AP24G); and NSF (MSB-ECA \#1802754 and INFEWS/T1 \#1739724).

\section{ACKNOWLEDGMENTS}

We would like to thank Greg Fiske and Carl Churchill for their expert assistance with cartography and data display. We would also like to thank Wanderley Rocha for help with graphic design and execution of the conceptual diagrams.

\section{SUPPLEMENTARY MATERIAL}

The Supplementary Material for this article can be found online at: https://www.frontiersin.org/articles/10.3389/ffgc.2021. 645282/full\#supplementary-material 


\section{REFERENCES}

Alencar, A., Moutinho, P., Arruda, V., Balzani, C., and Ribeiro, J. (2019). Amazon Burning: Locating the fires. Available online at: https://ipam.org.br/wp-content/ uploads/2019/09/AmazonBurning_LocatingTheFires.pdf (accessed December 2, 2019).

Andela, N., Morton, D. C., Giglio, L., Paugam, R., Chen, Y., Hantson, S., et al. (2019). The Global Fire Atlas of individual fire size, duration, speed and direction. Earth Syst. Sci. Data 11, 529-552. doi: 10.5194/essd-11-529-2019

Angelo, C., and Rittl, C. (2019). Is Brazil on the way to meet its climate targets? Explainer note by the Climate Observatory. Rio de Janeiro: Observatório do Clima, 1-10.

Aragão, L. E., Anderson, L. O., Fonseca, M. G., Rosan, T. M., Vedovato, L. B., Wagner, F. H., et al. (2018). 21st Century drought-related fires counteract the decline of Amazon deforestation carbon emissions. Nat. Commun. 9, 1-12. doi: 10.1038/s41467-017-02771-y

Artaxo, P. (2019). Working together for Amazonia. Science 363:323. doi: 10.1126/ science.aaw6986

Asner, G. P., Knapp, D. E., Broadbent, E. N., Oliveira, P. J., Keller, M., and Silva, J. N. (2005). Selective logging in the Brazilian Amazon. Science 310, 480-482. doi: 10.1126/science.1118051

Azevedo-Ramos, C., and Moutinho, P. (2018). No man's land in the Brazilian Amazon: could undesignated public forests slow Amazon deforestation?. Land Use Policy 73, 125-127. doi: 10.1016/j.landusepol.2018.01.005

Azevedo-Ramos, C., Moutinho, P., Arruda, V. L. D. S., Stabile, M. C., Alencar, A., Castro, I., et al. (2020). Lawless land in no man's land: the undesignated public forests in the Brazilian Amazon. Land Use Policy 99:104863. doi: 10.1016/j. landusepol.2020.104863

Baccini, A., Walker, W., Carvalho, L., Farina, M., Sulla-Menashe, D., and Houghton, R. A. (2017). Tropical forests are a net carbon source based on aboveground measurements of gain and loss. Science 358, 230-234. doi: 10. 1126/science.aam5962

Barber, C. P., Cochrane, M. A., Souza, C. M. Jr., and Laurance, W. F. (2014). Roads, deforestation, and the mitigating effect of protected areas in the Amazon. Biol. Conserv. 177, 203-209. doi: 10.1016/j.biocon.2014.07.004

Barlow, J., Berenguer, E., Carmenta, R., and França, F. (2020). Clarifying Amazonia's burning crisis. Glob. Change Biol. 26, 319-321. doi: $10.1111 / \mathrm{gcb}$. 14872

Barlow, J., Peres, C. A., Lagan, B. O., and Haugaasen, T. (2003). Large tree mortality and the decline of forest biomass following Amazonian wildfires. Ecol. Lett. 6, 6-8. doi: 10.1046/j.1461-0248.2003.00394.x

Brando, P. M., Soares-Filho, B., Rodrigues, L., Assunção, A., Morton, D., Tuchschneider, D., et al. (2020). The gathering firestorm in southern Amazonia. Sci. Adv. 6:eaay1632. doi: 10.1126/sciadv.aay 1632

Brienen, R. J., Phillips, O. L., Feldpausch, T. R., Gloor, E., Baker, T. R., Lloyd, J., et al. (2015). Long-term decline of the Amazon carbon sink. Nature 519, 344-348. doi: 10.1038 /nature 14283

Brinck, K., Fischer, R., Groeneveld, J., Lehmann, S., De Paula, M. D., Pütz, S., et al. (2017). High resolution analysis of tropical forest fragmentation and its impact on the global carbon cycle. Nat. Commun. 8:14855. doi: 10.1038/ ncomms 14855

Brown, D. S., Brown, J. C., and Brown, C. (2016). Land occupations and deforestation in the Brazilian Amazon. Land Use Policy 54, 331-338. doi: 10.1016/j.landusepol.2016.02.003

Bullock, E. L., Woodcock, C. E., Souza, C. Jr., and Olofsson, P. (2020). Satellitebased estimates reveal widespread forest degradation in the Amazon. Glob. Change Biol. 26, 2956-2969. doi: 10.1111/gcb.15029

Ceddia, M. G., Bardsley, N. O., Gomez-y-Paloma, S., and Sedlacek, S. (2014). Governance, agricultural intensification, and land sparing in tropical South America. Proc. Natl. Acad. Sci. U. S. A. 111, 7242-7247. doi: 10.1073/pnas. 1317967111

Climate Action Tracker. (2020). Brazil, Current Policy Projections. Available online at: https://climateactiontracker.org/countries/brazil/current-policyprojections/ (accessed December 12, 2020).

Cochrane, M. A., Alencar, A., Schulze, M. D., Souza, C. M., Nepstad, D. C., Lefebvre, P., et al. (1999). Positive feedbacks in the fire dynamic of closed canopy tropical forests. Science 284, 1832-1835. doi: 10.1126/science.284.5421. 1832
Curtis, P. G., Slay, C. M., Harris, N. L., Tyukavina, A., and Hansen, M. C. (2018). Classifying drivers of global forest loss. Science 361, 1108-1111. doi: 10.1126/ science.aau3445

de Azevedo, T. R., Junior, C. C., Junior, A. B., dos Santos Cremer, M., Piatto, M., Tsai, D. S., et al. (2018). SEEG initiative estimates of Brazilian greenhouse gas emissions from 1970 to 2015. Nat. Sci. Data 5:180045. doi: 10.1038/sdata. 2018.45

Escobar, H. (2019a). Amazon fires clearly linked to deforestation, scientists say. Science 365, 853-853. doi: 10.1126/science.365.6456.853

Escobar, H. (2019b). Bolsonaro's first moves have Brazilian scientists worried. Science 363, 330-330. doi: 10.1126/science.363.6425.330

Fearnside, P. M. (2008). The roles and movements of actors in the deforestation of Brazilian Amazonia. Ecol. Soc. 13:23. doi: 10.5751/ES-02451-130123

Fellows, M., Paye, V., Alencar, A., Nicácio, M., Castro, I., Coelho, M. E., et al. (2020). They Are not Numbers. They Are Lives! Technical Note No. Brasília: IPAM.

Fiocruz, and ICICT. (2021). "Covid-19 and the fires in the Legal Amazon and Pantanal: cumulative effects and vulnerabilities",in Technical Note, Observatório de Clima e Saúde. Fundação Osvaldo Cruz (Fiocruz) and Instituto de Comunicação e Informação Científica e Tecnológica em Saúde (ICICT). Brasil: ICICT.

Governors Climate and Forest Task Force (GCFTF). (2017). Guiding Principles for Collaboration and Partnership Between Subnational Governments, Indigenous Peoples and Local Communities. Available online at: https://www.gcftf.org/ resource/guiding-principles/ (accessed October 22, 2020).

Hansen, M. C., Potapov, P. V., Moore, R., Hancher, M., Turubanova, S. A., Tyukavina, A., et al. (2013). High-resolution global maps of 21st-century forest cover change. Science 342, 850-853. doi: 10.1126/science.1244693

Harris, N. L., Gibbs, D. A., Baccini, A., Birdsey, R. A., De Bruin, S., Farina, M., et al. (2021). Global maps of twenty-first century forest carbon fluxes. Nat. Clim. Chang. 11, 234-240. doi: 10.1038/s41558-020-00976-6

Houghton, R. A., Skole, D. L., Nobre, C. A., Hackler, J. L., Lawrence, K. T., and Chomentowski, W. H. (2000). Annual fluxes of carbon from deforestation and regrowth in the Brazilian Amazon. Nature 403, 301-304. doi: 10.1038/35002062

Hubau, W., Lewis, S. L., Phillips, O. L., Affum-Baffoe, K., Beeckman, H., CuníSanchez, A., et al. (2020). Asynchronous carbon sink saturation in African and Amazonian tropical forests. Nature 579, 80-87. doi: 10.1038/s41586-0202035-0

Human Rights Watch (HRW), Amazon Environmental Research Institute (Ipam), and Institute for Health Policy Studies (Ihps). (2020). The Air Is Unbearable" Health Impacts of Deforestation-Related Fires. New York: Human Rights Watch.

Instituto Nacional de Pesquisas Espaciais (INPE). (2020). Deforestation increments in the Brazilian Legal Amazon. Available online at: http://terrabrasilis.dpi.inpe. br/app/dashboard/deforestation/biomes/legal_amazon/increments (accessed October 14, 2020)

Instituto Nacional de Pesquisas Espaciais (INPE). (2021). Monitoring Active Fires by Biome. Programa Queimadas, Brazilian Institute for Space Research (INPE). Available online at: https://queimadas.dgi.inpe.br/queimadas/portalstatic/estatisticas_estados (accessed February 15, 2021).

Junior, C. H. S., Aragão, L. E., Anderson, L. O., Fonseca, M. G., Shimabukuro, Y. E., Vancutsem, C., et al. (2020). Persistent collapse of biomass in Amazonian forest edges following deforestation leads to unaccounted carbon losses. Sci. $A d v$. 6:eaaz8360. doi: $10.1126 /$ sciadv.aaz8360

Laurance, W. F. (2000). Do edge effects occur over large spatial scales?. Trends Ecol. Evol. 15:134. doi: 10.1016/s0169-5347(00)01838-3

Lewis, S. L., Brando, P. M., Phillips, O. L., van der Heijden, G. M., and Nepstad, D. (2011). The 2010 amazon drought. Science 331, 554-554. doi: 10.1126/science. 1200807

Macedo, M. N., DeFries, R. S., Morton, D. C., Stickler, C. M., Galford, G. L., and Shimabukuro, Y. E. (2012). Decoupling of deforestation and soy production in the southern Amazon during the late 2000s. Proc. Natl. Acad. Sci. 109, 1341-1346. doi: 10.1073/pnas.1111374109

MapBiomas. (2020). Mapbiomas, Collection 5. Available online at: https:// mapbiomas.org/ (accessed November 15, 2020).

Matricardi, E. A. T., Skole, D. L., Costa, O. B., Pedlowski, M. A., Samek, J. H., and Miguel, E. P. (2020). Long-term forest degradation surpasses deforestation in the Brazilian Amazon. Science 369, 1378-1382. doi: 10.1126/science. abb3021 
Maxwell, S. L., Evans, T., Watson, J. E., Morel, A., Grantham, H., Duncan, A., et al. (2019). Degradation and forgone removals increase the carbon impact of intact forest loss by $626 \%$. Sci. Adv. 5:eaax2546. doi: 10.1126/sciadv.aax2546

Moutinho, P., Guerra, R., and Azevedo-Ramos, C. (2016). Achieving zero deforestation in the Brazilian Amazon: What is missing?. Elementa: Science of the Anthropocene, 4. doi: 10.12952/journal.elementa.000125

Nepstad, D., Carvalho, G., Barros, A. C., Alencar, A., Capobianco, J. P., Bishop, J., et al. (2001). Road paving, fire regime feedbacks, and the future of Amazon forests. For. Ecol. Manag. 154, 395-407. doi: 10.1016/s0378-1127(01) 00511-4

Nepstad, D., McGrath, D., Stickler, C., Alencar, A., Azevedo, A., Swette, B., et al. (2014). Slowing Amazon deforestation through public policy and interventions in beef and soy supply chains. Science 344, 1118-1123. doi: 10.1126/science. 1248525

Nobre, C. A., Sampaio, G., Borma, L. S., Castilla-Rubio, J. C., Silva, J. S., and Cardoso, M. (2016). Land-use and climate change risks in the Amazon and the need of a novel sustainable development paradigm. Proc. Natl. Acad. Sci.U. S. A. 113, 10759-10768. doi: 10.1073/pnas.1605516113

Nobre, C. A., Sellers, P. J., and Shukla, J. (1991). Amazonian deforestation and regional climate change. J. Clim. 4, 957-988. doi: 10.1175/1520-0442(1991) 004<0957:adarcc $>2.0$. co; 2

Nolte, C., Agrawal, A., Silvius, K. M., and Soares-Filho, B. S. (2013). Governance regime and location influence avoided deforestation success of protected areas in the Brazilian Amazon. Proc. Natl. Acad. Sci. 110, 4956-4961. doi: 10.1073/ pnas. 1214786110

Pan, Y., Birdsey, R. A., Fang, J., Houghton, R., Kauppi, P. E., Kurz, W. A., et al. (2011). A large and persistent carbon sink in the world's forests. Science 333, 988-993. doi: 10.1126/science. 1201609

Phillips, O. L., Aragão, L. E., Lewis, S. L., Fisher, J. B., Lloyd, J., López-González, G., et al. (2009). Drought sensitivity of the Amazon rainforest. Science 323, 1344-1347. doi: 10.1126/science.1164033

Porter-Bolland, L., Ellis, E. A., Guariguata, M. R., Ruiz-Mallén, I., NegreteYankelevich, S., and Reyes-García, V. (2012). Community managed forests and forest protected areas: an assessment of their conservation effectiveness across the tropics. For. Ecol. Manag. 268, 6-17. doi: 10.1016/j.foreco.2011.05.034

Raftopoulos, M., and Morley, J. (2020). Ecocide in the Amazon: the contested politics of environmental rights in Brazil. Int. J. Hum. Rights 24, 1-26. doi: 10.1080/13642987.2020.1746648

RAISG (2020). Pan Amazon, Indigenous Land and Protected Area boundaries. Available online at: https://raisg.socioambiental.org (Accessed October 30, 2020).

Roe, S., Streck, C., Obersteiner, M., Frank, S., Griscom, B., Drouet, L., et al. (2019). Contribution of the land sector to a 1.5 C world. Nat. Clim. Chang. 9, 817-828. doi: 10.1038/s41558-019-0591-9

Serviço Florestal Brasileiro (SFB). (2017). National Forest Registry, Brazilian Forest Service (SFB). Available online at: https://www.florestal.gov.br/ (accessed April $10,2021)$

Silva, C. V., Aragão, L. E., Barlow, J., Espirito-Santo, F., Young, P. J., Anderson, L. O., et al. (2018). Drought-induced Amazonian wildfires instigate a decadalscale disruption of forest carbon dynamics. Philos. Trans. R. Soc. B Biol. Sci. 373:20180043. doi: 10.1098/rstb.2018.0043

Silva, C. V., Aragao, L. E., Young, P. J., Espirito-Santo, F., Berenguer, E., Anderson, L. O., et al. (2020). Estimating the multi-decadal carbon deficit of burned Amazonian forests. Environ. Res. Lett. 15:114023. doi: 10.1088/1748-9326/ abb62c

Silvério, D. V., Brando, P. M., Bustamante, M. M., Putz, F. E., Marra, D. M., Levick, S. R., et al. (2019). Fire, fragmentation, and windstorms: a recipe for tropical forest degradation. J. Ecol. 107, 656-667. doi: 10.1111/1365-2745.13076

Soares-Filho, B., Moutinho, P., Nepstad, D., Anderson, A., Rodrigues, H., Garcia, R., et al. (2010). Role of Brazilian Amazon protected areas in climate change mitigation. Proc. Natl. Acad. Sci. U. S. A. 107, 10821-10826. doi: 10.1073/pnas. 0913048107

Soares-Filho, B., Rajão, R., Macedo, M., Carneiro, A., Costa, W., Coe, M., et al. (2014). Cracking Brazil's Forest Code. Science 344, 363-364. doi: 10.1126/ science. 1246663

Soares-Filho, B., Rajão, R., Merry, F., Rodrigues, H., Davis, J., Lima, L., et al. (2016). Brazil's market for trading forest certificates. PLoS One 11:e0152311. doi: 10.1371/journal.pone.0152311
Souza, C. M. Jr., Siqueira, J. V., Sales, M. H., Fonseca, A. V., Ribeiro, J. G., Numata, I, et al. (2013). Ten-year Landsat classification of deforestation and forest degradation in the Brazilian Amazon. Remote Sens. 5, 5493-5513. doi: $10.3390 /$ rs5115493

Sparovek, G., Reydon, B. P., Pinto, L. F. G., Faria, V., de Freitas, F. L. M., AzevedoRamos, C., et al. (2019). Who owns Brazilian lands? Land Use Policy 87:104062. doi: 10.1016/j.landusepol.2019.104062

Spracklen, B. D., Kalamandeen, M., Galbraith, D., Gloor, E., and Spracklen, D. V. (2015). A global analysis of deforestation in moist tropical forest protected areas. PloS One 10:e0143886. doi: 10.1371/journal.pone.01 43886

Stabile, M. C., Guimarães, A. L., Silva, D. S., Ribeiro, V., Macedo, M. N., Coe, M. T., et al. (2020). Solving Brazil's land use puzzle: increasing production and slowing Amazon deforestation. Land Use Policy 91:104362. doi: 10.1016/j.landusepol. 2019.104362

SEEG. (2021). Emissions from land use change. Greenhouse Gas Emissions and Removal Estimation System (SEEG-Brasil), Climate Observatory. Available online at: http://seeg.eco.br/ (accessed April 10, 2021)

Strassburg, B. B., Brooks, T., Feltran-Barbieri, R., Iribarrem, A., Crouzeilles, R., Loyola, R., et al. (2017). Moment of truth for the Cerrado hotspot. Nat. Ecol. Evol. 1:0099. doi: 10.1038/s41559-017-0099

Strassburg, B. B., Latawiec, A. E., Barioni, L. G., Nobre, C. A., Da Silva, V. P., Valentim, J. F., et al. (2014). When enough should be enough: improving the use of current agricultural lands could meet production demands and spare natural habitats in Brazil. Glob. Environ. Chang. 28, 84-97. doi: 10.1016/j.gloenvcha. 2014.06.001

Tyukavina, A., Hansen, M. C., Potapov, P. V., Stehman, S. V., Smith-Rodriguez, K., Okpa, C., et al. (2017). Types and rates of forest disturbance in Brazilian Legal Amazon, 2000-2013. Sci. Adv. 3:e1601047. doi: 10.1126/sciadv.1 601047

UNDESA. (2007). United Nations Declaration on the Rights of Indigenous Peoples. Available online at: https://www.un.org/development/desa/indigenouspeoples/ declaration-on-the-rights-of-indigenous-peoples.html (accessed October 21, 2020).

UNFCCC. (2020). NDC registry, Brazil's Nationally Determined Contribution (NDC). Available online at: https://www4.unfccc.int/sites/ndcstaging/Published Documents/Brazil\%20First/BRAZIL\%20iNDC\%20english\%20FINAL.pdf (accessed December 12, 2020).

Walker, W., Baccini, A., Schwartzman, S., Ríos, S., Oliveira-Miranda, M. A., Augusto, C., et al. (2014). Forest carbon in Amazonia: the unrecognized contribution of indigenous territories and protected natural areas. Carbon Manag. 5, 479-485. doi: 10.1080/17583004.2014.990680

Walker, W. S., Gorelik, S. R., Baccini, A., Aragon-Osejo, J. L., Josse, C., Meyer, C., et al. (2020). The role of forest conversion, degradation, and disturbance in the carbon dynamics of Amazon indigenous territories and protected areas. Proc. Natl. Acad. Sci. U. S. A. 117, 3015-3025. doi: 10.1073/pnas. 1913321117

West, T. A. P., and Fearnside, P. M. (2021). Brazil's conservation reform and the reduction of deforestation in Amazonia. Land Use Policy 100, 1-12. doi: 10.1016/j.landusepol.2020.105072

Conflict of Interest: The authors declare that the research was conducted in the absence of any commercial or financial relationships that could be construed as a potential conflict of interest.

Publisher's Note: All claims expressed in this article are solely those of the authors and do not necessarily represent those of their affiliated organizations, or those of the publisher, the editors and the reviewers. Any product that may be evaluated in this article, or claim that may be made by its manufacturer, is not guaranteed or endorsed by the publisher.

Copyright (C) 2021 Kruid, Macedo, Gorelik, Walker, Moutinho, Brando, Castanho, Alencar, Baccini and Coe. This is an open-access article distributed under the terms of the Creative Commons Attribution License (CC BY). The use, distribution or reproduction in other forums is permitted, provided the original author(s) and the copyright owner(s) are credited and that the original publication in this journal is cited, in accordance with accepted academic practice. No use, distribution or reproduction is permitted which does not comply with these terms. 